\title{
ИНКЛЮЗИВНОЕ ТРУДОУСТРОЙСТВО В РОССИИ: ПРОБЕЛЫ В ПРАВЕ И СПОСОБЫ ИХ ПРЕОДОЛЕНИЯ
}

\author{
(ㄷ 2018 Даова Фатима Хазреталиевна \\ Институт права, экономики и финансов \\ Кабардино-Балкарский государственный университет имени Х.М. Бербекова \\ 360004, г. Нальчик, ул. Чернышевского 173 \\ (c) 2018 Шаваева Диана Вячеславовна \\ Институт права, экономики и финансов \\ Кабардино-Балкарский государственный университет имени Х.М. Бербекова \\ 360004, г. Нальчик, ул. Чернышевского 173 \\ (c) 2018 Литягина Алла Сергеевна \\ старший преподаватель \\ Институт права, экономики и финансов \\ Кабардино-Балкарский государственный университет имени Х.М. Бербекова \\ 360004, г. Нальчик, ул. Чернышевского 173 \\ (c) 2018 Кокова Лиана Руслановна \\ доцент \\ Институт права, экономики и финансов \\ Кабардино-Балкарский государственный университет имени Х.М. Бербекова \\ 360004, г. Нальчик, ул. Чернышевского 173

\section{(c) 2018 Куашев Артур Каншобиевич \\ Судья \\ Чегемский районный суд \\ Кабардино-Балкарская Республика}

В статье рассматривается важность и необходимость интеграции инвалидов в общественно-полезное производство. В ходе исследования выделены способы повышения доступности трудоустройства для людей с ограниченными возможностями здоровья. В качестве выводов предложены ряд положений по ликвидации пробелов в праве и коллизий в действующем законодательстве в сфере социально-трудовой защиты инвалидов.

Ключевые слова: инвалид, интеграция, рынок труда, безработица, трудоустройство, социальная защита, занятость, закон.

Инклюзивное трудоустройство подразумевает физически доступное рабочее место и отношение, поощряющее вовлечение в работу лиц с инвалидностью. Актуальность темы обусловлена возросшей практической значимостью проблемы регулирования занятости людей с ограниченными возможностями, связанной с постоянно меняющимися условиями функционирования рынка труда, усилением дискриминации инвалидов и трансформацией российского общества. Объектом исследования выступает система интеграции инвалидов в сферу труда, призванная решать проблемы занятости и преодоления безработицы среди инвалидов и обеспечивать их социально-экономическую без- опасность. Цель статьи - выявить пробелы в праве и коллизии в действующем законодательстве, регулирующем вопросы занятости инвалидов на российском рынке труда, и предложить рациональные пути решения выявленных проблем.

Итак, «инвалидность представляет собой социальный феномен» [2], избежать которого не может ни одно общество, и каждое государство сообразно уровню своего развития, приоритетам и возможностям формирует социально-экономическую политику в отношении инвалидов.

По официальным данным, численность российских инвалидов превышает 11 млн. человек, и 
только 14\% инвалидов трудоспособного возраста вовлечено в профессиональную деятельность. Для сравнения, в США из 54 миллионов инвалидов трудоустроено 31\%, в Великобритании из 5 миллионов 43\%, в Китае из 60 миллионов инвалидов трудоустроено 82\%. Сложившиеся низкие показатели занятости и трудоустройства инвалидов в Российской Федерации аргументируются колоссальным преимуществом спроса над предложением на рынке труда. Потребность взрослых инвалидов в профессиональной реабилитации по статистическим данным составляет по России 80,7\% [4]. Данная цифра в разы превышает количество спроса на работников с ограниченными возможностями здоровья.

Разработка конкретных предложений в части регулирования вопрооов занятости и трудоустройства лиц с инвалидностью и ограниченными возможностями здоровья вызвана необходимостью более точного учета положений статьи 27 Конвенции ООН о правах инвалидов на получение возможности зарабатывать себе на жизнь трудом, в условиях, когда рынок труда и производственная среда являются открытыми, инклюзивными и доступными для инвалидов.

Федеральные органы государственной власти, органы государственной власти субъектов Российской Федерации в соответствии со статьей 20 Федерального закона от 24.11.1995 N181Ф3 «О социальной защите инвалидов в Российской Федерации» в редакции от 19.12.2016 (далее - Закон), предоставляют инвалидам гарантии трудовой занятости путем проведения специальных мероприятий. Однако для повышения конкурентоспособности людей с ограниченными возможностями государству необходимо осуществлять наряду с существующими мероприятиями и льготно-правовую политику. Основными целями данной политики выступают усовершенствование системы льгот, выработка путей повышения их эффективности, что в результате приведет к согласованию интересов личности, социальных групп и государства. Для достижения поставленных целей льготно-правовая политика использует в основном позитивные средства, такие как льготы, компенсации, поощрения, государственные награды (как особый вид поощрений). Применение любого из вышеуказанных средств способствует обеспечению равенства граждан, улучшению их социально-экономического уровня, облегчению доступа к юридически обеспеченному праву.

В соответствии с частью 1 статьи 21 Закона, организациям, численность работников которых составляет более 100 человек, законодательством субъекта Российской Федерации устанавливается квота для приема на работу инвалидов в размере от 2 до 4 процентов среднесписочной численности работников. В целях расширения возможностей трудоустройства инвалидов на открытом рынке труда целесообразным будет повышение минимального числа рабочих мест для особо нуждающихся в социальной защите и испытывающих трудности в поиске работы граждан. Указанная норма положительно скажется на ситуации, связанной с дефицитностью рабочих мест для людей с ограниченными возможностями здоровья.

Для защиты прав инвалидов на безопасные и здоровые условия труда необходимо инициировать более четкое закрепление на законодательном уровне создание специальных рабочих мест в соответствии с Санитарными правилами 2.2.9.2510-09 «Гигиенические требования к условиям труда инвалидов», утвержденные постановлением Главного государственного санитарного врача Российской Федерации от 18 мая 2009 года, которые должны соблюдаться предприятиями всех отраслей экономической деятельности. Результатами применения императивной нормы послужат предотвращение или сведение к минимуму негативных последствий применения труда инвалидов в условиях производства, создание гигиенически безопасных условий труда с учетом анатомо-физиологических особенностей их организма.

В действующей редакции Закона не закреплена информация об условиях привлечения инвалидов к сверхурочным работам в праздничные дни. Указанное дополнение позволит устранить вопросы, возникающие в правоприменительной практике при защите интересов работников-инвалидов, касающихся трудовой деятельности в нерабочие праздничные дни.

В целом предлагаемые коррективы являются необходимым условием для повышения государственных гарантий обеспечения прав занятости и трудоустройства особой категории граждан на рынке труда, предоставления помощи уже трудоустроенным инвалидам, преодоления явлений социал-дарвинизма в обществе, усилившихся в условиях рыночной экономики, и способствуют избежать проблемы маргинали- 
зации населения.

Необходимость занятости инвалидов с экономической стороны связана, прежде всего, с обеспеченностью общественного производства рабочей силой, снижением иждивенцев, финансирующихся из бюджета государства.

Решение проблем занятости инвалидов, обеспечивающих защиту интересов целых слоев или групп населения, позволит на макроуровне укрепить национальную безопасность и обеспечить соцальную стабильность общества. Решение проблем на микроуровне позволит снизить уровень безработицы на сегменте рынка труда, детерменировать качество жизни инвалидов в лучшую сторону и обеспечить их социально-когнитивную адаптацию в обществе.

По сути, низкая занятость и безработица инвалидов объясняется не только пробелами в правовой базе, но и консервативным мировоз- зрением общества на эти проблемы. В развитых странах преобладает мнение, что такие проявления дискриминации, как экономическое и психологическое давление, ограничение доступа к социальным благам не могут быть решены только путем оптимизации трудового законодательства. Необходимо изменить ментальность, приоритеты и принципы построения социальной сферы и отношение к особым социальным группам. При этом, человека с инвалидностью следует рассматривать не как пассивного получателя помощи и поддержки, а, в первую очередь, учитывать его жизненную силу и энергию, индивидуальные, культурные и гендерные отличия. Только изменив мировосприятие и миропонимание людей можно надеяться на то, что проблемы занятости и трудоустройства инвалидов в современном обществе исчерпают всю свою острот

\section{Библиографический список}

1. Новиков М. Л., Веселов М.Ю. Государственная политика в отношении трудовой занятости людей с инвалидностью: международный опыт и российская практика. Москва. 2008. 141 с.

2. Никитин Д. А. Трудоустройство инвалидов: интегрированный подход. Москва. 2009. 32 с.

3. Новиков М. Возможности и условия расширения занятости инвалидов. // Человек и труд. 2008. № 10. С. 4-6.

4. Труд и занятость в России. 2015: Статистический сборник / Ред. колл.: К.Э. Лайкам, В.Е. Гимпельсон, О.Б. Жихарева и др. Москва. 2015. 274 с. 